\title{
The Hangzhou Consensus: Legacy for China, G20 and the World ${ }^{1}$
}

\author{
M. Larionova, O. Kolmar
}

Marina Larionova - PhD, Head of the Centre for International Institutions Research, Russian Presidential Academy of National Economy and Public Administration, 11 Prechistenskaya Naberezhnaya, Moscow, Russia 119034; E-mail: larionova-mv@ranepa.ru

Olga Kolmar - Researcher, Centre for International Institutions Research, Russian Presidential Academy of National Economy and Public Administration; 11 Prechistenskaya Naberezhnaya, Moscow, Russia 119034; E-mail: kolmar-oi@ranepa.ru

\begin{abstract}
China took over the G20 2016 presidency from Turkey during a period of subdued economic activity and diminished global growth. Growth in China was expected to slow to $6.3 \%$ in 2016 and $6.0 \%$ in 2017, primarily reflecting weaker investment growth as the economy continued to rebalance. Acknowledging that lower growth rates have become the "new normal," the Chinese leadership set the annual target growth rate for China at no less than $6.5 \%$ in its $13^{\text {th }}$ Five-Year Plan (2016-2020). The Plan redefined China's development paradigm, de-emphasizing speed in favour of quality based on innovation, coordination, green development, openness and sharing. This vision constituted the foundation of China's concept and priorities for the G20 presidency. The article reviews the main outcomes of the Chinese G20 presidency, focusing on major results which reflect China's priorities for domestic development and international cooperation. Using qualitative and quantitative analysis of the G20 2016 documents and the documents of international organizations, the author highlights the key decisions made at the Hangzhou summit and trends in G20 engagement with international institutions.

The findings indicate that the Chinese presidency's priorities of development, innovation and trade received unprecedented attention, with development reaching an almost $43 \%$ share in the discourse (compared to the average of $15 \%$ for the eleven summits), innovation rising tenfold to about $7 \%$ (compared to $0.75 \%$ for the eleven summits) and trade peaking to $7.3 \%$ (compared to the average rate of $2.8 \%$ ). At $2.2 \%$, the share of the G20 discourse dedicated to the environment was higher than the overall average (1.42\%) and higher than at any other summit except Cannes and Los Cabos. While energy issue-related discourse (about 4\%) ranked lower than for Brisbane and Antalya, the metric was comparable to the average for the period (3.4\%). Discussion dedicated to economic issues (25\%) was close to the average for the period (27\%). In line with the historical trend, the share of finance issues in the G20 discourse continued to decline, reflecting the G20's role in the division of labour with regards to the regulation of financial markets.

The intensity of G20 engagement with international organizations was higher than the average since the Washington summit. The choice of organizations was defined by the presidency's priorities and established trends. Given the UN's role in setting Sustainable Development Goals, and China's commitment to the UN as the central element of a fair and peaceful multilateral system, it came as no surprise that the intensity of references to the UN was twice as high as the average for G20 summits and significantly higher than in any other summit. A similar trend was observed with respect to the WTO and UNCTAD. The G20's reliance on OECD expertise continued to rise. The intensity of G20 engagement with the IMF and the World Bank was slightly lower than during the previous presidencies. Last but not least, China consolidated the G2O's dialogue with engagement groups, most notably with B20 and L2O.
\end{abstract}

${ }^{1}$ The editorial board received the article in January 2017.

The research was carried out within the framework of the RANEPA research project "Assessment of the G20 and BRICS effectiveness on the basis of monitoring compliance with the summits`commitments". 
Drawing on the results of qualitative and quantitative analysis, the author concludes that China's G20 presidency contributed to the country's development priorities, reflected China's role in the evolving world order, and consolidated the G20's status as the premier forum for economic cooperation and making globalization work for everyone. The author asserts that China managed to ensure its imprint on future G20 cooperation. First, it did so by integrating innovation, the new industrial revolution and the digital economy into its core agenda, generating 137 commitments to innovative growth and setting up the relevant international mechanisms. Second, with respect to trade and investment, it facilitated development and the adoption of two documents defining guiding principles for global investment policymaking, and promoting inclusive trade and global value chains. Third, under China's stewardship, the G20 agreed to three action plans on energy cooperation, including Enhancing Energy Access in Asia and the Pacific: Key Challenges and G20 Voluntary Collaboration Action Plan, the G20 Voluntary Action Plan on Renewable Energy, and the G20 Energy Efficiency Leading Program (EELP), making further progress to address energy access, a cleaner energy future, energy efficiency, global energy architecture, energy security, as well as market transparency. Fourth, China advanced further G20 cooperation on development based on the Action Plan of the 2030 Agenda for Sustainable Development. Fifth, the presidency committed to establish three China-based G20 centres, thus creating opportunities to enhance its influence in the G20 process through an evidence base, research and the exchange of knowledge in key policy areas. China struck a good balance between continuity and innovation regarding the G20 agenda, contributed to its legitimacy and effectiveness through productive engagement with key international organizations and dialogues with the engagement groups, and consolidated the G20's capacity for direction setting, decision making and delivery.

Key words: Global governance, international organizations, informal summit institutions, efficiency, legitimacy, innovation, new industrial revolution, digital economy, G20, China

For citation: Larionova M., Kolmar O. (2017) The Hangzhou Consensus: Legacy for China, G20 and the World. International Organisations Research Journal, vol. 12, no 3, pp. 53-72 (in Russian and English). DOI: 0.17323/1996-7845-2017-03-53

\section{Plans and Expectations}

China took over the G20 2016 presidency from Turkey "at a critical moment for the world economy, global governance and the institution-building of the G20 itself" [Wang, 2016b]. The International Monetary Fund (IMF) registered subdued economic activity and diminished growth prospects [IMF, 2016, pp. 1-2] and forecast global growth to be gradual, with $3.4 \%$ in 2016 and $3.6 \%$ in 2017. Growth in China was "expected to slow to $6.3 \%$ in 2016 and $6.0 \%$ in 2017, primarily reflecting weaker investment growth as the economy continues to rebalance" [IMF, 2016, p. 3]. Though lower than the country' performance in the previous years, it remained significantly higher than the global average, and second only to its neighbor India, set to grow at 7.5 in both 2016 and 2017 [IMF, 2016, p. 6]. While acknowledging that lower growth rates had become the "new normal," the Chinese leadership set the annual growth rate target for China to be no less than $6.5 \%$ in its $13^{\text {th }}$ Five-Year Plan (2016-2020) adopted at the fifth plenary session of the Communist Party of China's $18^{\text {th }}$ Central Committee. ${ }^{2}$ The $6.5 \%$

2 "Five-Year Plan to Speed up 'Hukou' Reform." Available at: http://english.cntv.cn/special/ fifthplenum_18th cpc/(accessed 15.01.2017). 
growth should allow China to realize its goal of becoming a moderately prosperous society in all respects [Xi, 2016] and avoid the middle income trap. ${ }^{3}$ The Plan redefined China's development paradigm from speed to quality and efficiency, based on innovation, coordination, green development, openness and sharing.

This vision and these aspirations constituted the foundation of China's concept and priorities for the G20 presidency, as outlined by President Xi Jinping at the Antalya (Turkey) summit in November 2015: "First, we need to transform growth patterns in innovative ways with particular focus on pursuing reform and innovation. We must create and seize new opportunities to raise the potential of global economic growth. Second, we need to improve global economic and financial governance, increase the representation and voice of emerging markets and developing countries, and enhance the capacity of the global economy to ward off risks. Third, we need to promote global trade and investment to generate growth and build an open world economy" [Xi, 2015a].

Like many of its predecessors in prior summits [Shelepov, 2013; Larionova et al., 2013; Larionova, 2011], China sought a balance between its national priorities and global governance challenges, as well as between continuity and innovation in setting the G20's agenda for 2016. The presidency's statement on the theme and key agenda items for the summit articulated China's commitment to spare no efforts to build an "innovative, invigorated, interconnected and inclusive world economy" [Chinese G20 Presidency, 2016]. To break a new path for growth, the presidency proposed the adoption of an innovation-driven development strategy, to deepen structural reforms and increase total-factor productivity, advance the emerging new industrial revolution and enhance exchanges and coordination in economic, innovation and entrepreneurship policies to reduce inconsistencies [Chinese G20 Presidency, 2016, pp. 3-5]. For the first time in G20 history, green finance was put on the G20 agenda. China expressed its commitment to work, in the spirit of partnership, to consolidate and strengthen the G20 core agenda of macroeconomic and fiscal policies coordination, structural reforms, international financial architecture and financial sector reforms, the promotion of trade growth and forging inclusive and integrated global value chains.

In explaining China's ten priorities for the 11th G20 summit, Chinese Foreign Minister Wang Yi emphasized that "the theme and topics proposed by China have received strong endorsement and support from other G20 members" [Wang, 2016a]. One hundred days into the presidency, the Minister spelt out the results China expected to achieve at the summit. First, China intended for a blueprint for innovationdriven growth to "lock on the fresh impetus to global growth but also lay out specific action plans through which to boost innovation, the new industrial revolution and the digital economy" [Wang, 2016a]. Second, an action plan for the implementation of the 2030 Agenda for Sustainable Development was proposed to put the development issue within a global macro-policy framework and give a strong impetus to the UN's sustainable development agenda. Third, China expected an indicator system for struc-

3 "Blueprint for the 13th Five-Year Plan for 2016-2020.” Available at: http://www.china-brain.com/Resources/ Blueprint-for-the-13th-Five-Year-Plan-for-2016-2020-/195.html\#.WGOu4y2LT3g (accessed 15.01. 2017). 
tural reforms to reenergize G20 members' efforts to implement structural reforms in nine priority areas. Fourth, the global trade growth strategy was aimed at reversing the ebbing growth of global trade through the coordination of trade and investment policies. Fifth, the adoption of a set of guiding principles for global investment was planned to facilitate cross-border cooperation on investment. Sixth, China hoped to advance completion of the IMF $15^{\text {th }}$ General Review of Quotas. Seventh, the launch of high-level principles on international fugitive repatriation and asset recovery, a research centre on anti-corruption cooperation and a two-year anti-corruption action plan (2017-2018) were planned, in order to put a squeeze on corruption in the G20 and beyond. Eighth, cooperation to support the industrialization of Africa and least developed countries (LDCs) was proposed to speed up industrialization and enhance their capacity for development. Ninth, a G20 entrepreneurship action plan was intended to provide a platform for the exchange of best practice and experience. Tenth, a push for early entry-into-force of the Paris Agreement on climate change was expected to contribute to international cooperation on climate change [Wang, 2016a].

To achieve the results the presidency had planned, the G20 and their partners worked on a very dense programme which included 23 ministerial-level meetings, including five Sherpa meetings, four finance ministers' and central bank governors' meetings, as well as four deputy finance minister and central bank deputies' meetings. The G20 ministers for agriculture held their fourth summit meeting, and the labour and employment ministers held their seventh meeting. Energy ministers held their second meeting, and trade ministers held their fourth. All in all, 26 documents were adopted, 12 of which were agreed upon by the leaders and 13 by the ministerial meetings. The international organizations contributed to the G20 decision-making, providing 40 reports, notes and discussion papers (nine were prepared by the IMF, while eight came from the Organisation for Economic Co-operation and Development (OECD), six were submitted by the Financial Stability Board (FSB), five by the World Trade Organization (WTO), three by the International Labour Organization (ILO), one by the World Bank (WB), and one by the United Nations Conference on Trade and Development (UNCTAD). The engagement partners came up with nine documents presenting proposals from Business20 and Labour20, Think20, Civil20, Youth20 and Women20. Most of the ministerial decisions and many proposals of the outreach groups found their way into the Leaders' communiqué, which featured 135 commitments in the key policy areas of G20 cooperation.

\section{China's Mark on the G20 Process and a Milestone in its History [Wang, 2016b]}

So what were the main outcomes of China's G20 presidency? It would take a book to compile a detailed analysis of all the deliverables from the Chinese G20 presidency. This paper focuses on several major results reflecting China's priorities for domestic development and international cooperation. The Hangzhou Consensus foundations of 
innovative growth, a combination of economic growth with social development and environment protection, an open world economy and economic growth which benefits all countries and all people are very much aligned with China's $13^{\text {th }}$ five-year plan and its vision of innovative, coordinated, green, open and shared development. For the first time in the history of G20 innovation, the industrial revolution and the digital economy were included in the G20's core agenda. The four documents devoted to these issues (the G20 Blueprint on Innovative Growth, the G20 2016 Innovation Action Plan, the G20 New Industrial Revolution Action Plan, and the G20 Digital Economy Development and Cooperation Initiative) spelled out 110 commitments. ${ }^{4}$ Together with the 27 commitments in the leaders' communiqué, they laid a solid foundation for the G20's future agenda on innovation. Cooperation on the new agenda was institutionalized by the establishment of a "G20 Task Force supported by the OECD and other relevant international organizations to take forward the G20 agenda on innovation, the new industrial revolution and the digital economy, subject to the priorities of the respective future G20 presidencies, ensuring continuity and consistency with the results so far, and promoting synergies with other G20 workstreams" [G20 Leaders, 2016, para. 11].

The G20 2016 Innovation Action Plan mandated that the OECD and the WB support the G20 members' exchange of best practices and policies through a new online G20 Community of Practice (within the existing Innovation Policy Platform) and release of the 2016 G20 Innovation Report, which includes all G20 members and covers the measurable indicators. The G20 New Industrial Revolution Action Plan put forward an itemized course of action which focused on research, SME empowerment, standards and infrastructure for the NIR, and the industrialization of developing countries. The leaders asked the OECD, UNCTAD and UNIDO to prepare a G20 NIR Report providing an overview of opportunities and challenges brought about by NIR. The G20 Digital Economy Development and Cooperation Initiative made provisions for collective action to promote digital development and address the digital divide. It recognized the key role of adequate and effective IPR protection and the enforcement of all documents prioritizing cooperation on IPR, and pledged to engage with relevant international organizations, including the World Intellectual Property Organization (WIPO). Thus, with a targeted Task Force, multiple mandates for international organizations, new mechanisms for sharing knowledge and research to be carried out by the next G20 summit, cooperation on innovation, the digital economy and NIR was set in motion. Germany taking over from China made opportunities and risks arising from digital innovations one of the presidency priorities for G20 in 2017. By mid-January 2017, the OECD submitted to the G20 its recommendations for digital transformation in the G20, spanning a range of issues from access to digital infrastructures to digital security and legal frameworks. ${ }^{5}$

${ }^{4}$ G20 Blueprint on Innovative Growth - 23, G20 2016 Innovation Action Plan - 13, G20 New Industrial Revolution Action Plan - 27, G20 Digital Economy Development and Cooperation Initiative - 47 commitments.

${ }^{5}$ OECD (2017). "Key Issues for Digital Transformation in the G20.” Berlin, 12 January. Available at: https://www.oecd.org/g20/key-issues-for-digital-transformation-in-the-g20.pdf (accessed 15.01.2017). 
True to the G20's economic and financial governance reform mission, the Hangzhou decisions aimed to promote efficient global economic and financial governance, asking the IMF to complete the $15^{\text {th }}$ General Review of Quotas, including a new quota formula, by the 2017 Annual Meetings. encouraging the World Bank Group to implement its shareholding review according to the agreed-upon roadmap, timeframe and principles; and commending the ongoing examination of the broader use of the SDR, such as broader reporting in the SDR and the issuance of SDR-denominated bonds [G20 Leaders, 2016, para. 17], following successful issuance of SDR bonds by the World Bank in China's interbank market.

Commitments to finalize the remaining critical elements of the regulatory framework and the timely, full and consistent implementation of the agreed-upon financial sector reform agenda, including Basel III and the total-loss-absorbing-capacity (TLAC) standard as well as effective cross-border resolution regimes, contribute to China's efforts to make the RMB an international currency and further internationalize its financial sector.

International cooperation on taxation was taken further with the leaders' endorsement of several related OECD proposals. These pertained to objective criteria for identifying non-cooperating jurisdictions with respect to tax transparency, and tasking the OECD with preparing a list of those jurisdictions that have not yet sufficiently progressed toward a satisfactory level of implementation of the agreed-upon international standards on tax transparency by the July 2017 G20 Leaders' summit [G20 Leaders, 2016, para. 19]. Emphasizing the role effective tax policy plays in promoting innovation-driven and inclusive growth, China pledged to make its own contribution by establishing an international tax policy research centre for international tax policy design and research.

In line with China's priority to enhance international cooperation against corruption and the G20 Toronto pledge to lead by example in fighting corruption, the G20 leaders endorsed the 2017-2018 G20 Anti-Corruption Action Plan to improve public and private sector transparency and integrity and the G20 High Level Principles on Cooperation on Persons Sought for Corruption and Asset Recovery. The Anti-Corruption Working Group was asked to develop an implementation plan before the end of 2016. G20 welcomed Chinese initiative to establish a Research Centre on International Cooperation Regarding Persons Sought for Corruption and Asset Recovery in G20 Member States. The proposed Centre will be located in China and operate according to international norms [G20 Leaders, 2016, para. 22].

Energy cooperation received a new boost. The G20 adopted three new documents: the G20 Voluntary Collaboration Action Plan on Energy Access, the G20 Voluntary Action Plan on Renewable Energy and the G20 Energy Efficiency Leading Program. Additionally, the members reaffirmed their commitment to open, competitive, efficient, stable and transparent energy markets, stressed the importance of investment in energy projects for ensuring future energy security and preventing economically destabilizing price spikes, and promised to enhance collaboration on solutions that promote 
natural gas extraction, transportation, and processing in a manner that minimizes environmental impacts, given that it is a less emission-intensive fossil fuel.

The G20 Energy Efficiency Leading Program expands the G20 Energy Efficiency Action Plan to include five new key areas of collaboration. These are the Superefficient Equipment and Appliances Deployment initiative (SEAD), Best Available Technologies and Practices (TOP TENs), District Energy Systems (DES), the Energy Efficiency Knowledge Sharing Framework, and Energy End-Use-Data and Energy Efficiency Metrics. Through the G20 Voluntary Action Plan on Renewable Energy, the G20 aimed to scale-up investments in renewable energy technologies, products and services, within and beyond the G20 members. The Voluntary Action Plan for Enhancing Energy Access in Asia and the Pacific set a framework for closer international cooperation to promote innovative technological solutions, develop and scale up sustainable business models and increase financing and investment as a means to realize the goals set under the 2030 Agenda in Sustainable Development Goal 7 on energy. The G20 decisions on energy access and efficiency contribute to the global efforts to combat climate change, support China's intended nationally determined contribution under the Paris Agreement [China's National Focal Point for UNFCCC, 2015] and reinforce the country's domestic management agenda, as set up in the PRC Strategic Energy Action Plan (2014-2020) and national 13th Five-Year Plan.

China is heavily reliant on trade for its development, ranking first in the world in terms of exports and second in terms of imports. ${ }^{6}$ The People's Republic marked the $15^{\text {th }}$ anniversary of its WTO membership in December 2016. A member of 14 regional trade agreements, China regards FTAs as a platform for opening up its economy to the outside and speeding up domestic reforms. ${ }^{7}$ It pursues the completion of the Regional Comprehensive Economic Partnership, remains committed to the eventual realization of the Free Trade Area of the Asia Pacific (FTAAP), initiated during China's 2014 APEC presidency, and actively deploys the WTO mechanisms. ${ }^{8}$ Thus China seeks to balance its support for the multilateral trading regime ("read" WTO) with its pursuit of FTAs and investment treaties as well as the development of "high standard pilot free trade zones in China" [Xi, 2016]. China also needs access to foreign investment which is smarter, greener and more productive [OECD, 2016]. Therefore, strengthening international trade and investment was the focus of China's G20 presidency. Although the final outcomes of the summit did not quite measure up to Beijing's expectations, they were a step forward in G20 cooperation. Institutionally the G20 established a Trade and Investment Working Group (TIWG) and adopted two documents. The G20 Strategy for Global Trade Growth aims to lower trade costs, harness trade and investment policy coherence, boost trade in services, enhance trade finance, promote the

${ }^{6}$ WTO data for 2015. “China.” Available at: http://stat.wto.org/CountryProfiles/CN_E.htm (accessed 15.01.2017).

${ }^{7}$ China FTA Network. Available at: http://fta.mofcom.gov.cn/english/ (accessed 15.01.2017).

${ }^{8}$ China has acted/acts as compliant in 15 cases of the dispute cases and as respondent in 38 cases. WTO. "China and the WTO." Available at: https://www.wto.org/english/thewto_e/countries_e/china_e.htm (accessed 15.01.2017). 
development of e-commerce, and address trade and development [G20 Trade Ministers, 2016b]. The G20 Guiding Principles for Global Investment Policymaking were proposed to provide general guidance for investment policymaking with the objective of (i) fostering an open, transparent and investment-conducive global policy environment, (ii) promoting coherence in national and international investment policymaking, and (iii) promoting inclusive economic growth and sustainable development [G20 Trade Ministers, 2016c]. However, their statement on regional trade arrangements' coherence with the WTO, "We commit to working to ensure our bilateral and regional trade agreements complement the multilateral trading system, and are open, transparent, inclusive and WTO-consistent" [G20 Leaders, 2016, para. 27], was weaker than that of their trade ministers, who also promised to "work with other WTO members towards the transformation of the provisional Transparency Mechanism on RTAs into a permanent one and commit to lead by example in fully fulfilling related notification obligations" [G20 Trade Ministers, 2016a, para. 13].

The G20 Action Plan on the 2030 Agenda for Sustainable Development aligned G20 development cooperation with the 2030 Agenda for Sustainable Development. It defined the principles and priority issues, ${ }^{9}$ as well G20 members' national actions. Importantly, it upgraded the DWG's status, which was mandated to act as a coordinating body and policy resource for sustainable development across the G20. It was tasked to assist "in the delivery of 2030 Agenda-related activities, working closely with other G20 work streams in the Sherpa and Finance tracks, by facilitating two-way exchanges of information, providing advice to other work streams on development-related issues and 2030 Agenda priorities, and helping to identify in each presidency the division of labour between the DWG and other work streams with an aim to strengthen the integration of the 2030 Agenda in G20 work programs and ensure that responsibility for the implementation and tracking progress of specific issues is clear" [G20, 2016, p. 17].

The presidency saw two new initiatives in infrastructure as one of the key areas in the G20's development cooperation agenda. Eleven major multilateral development banks (MDBs), including the recently-established Asian Infrastructure Investment Bank (AIIB) and New Development Bank (NDB), issued a "Joint Declaration of Aspirations on Actions to Support Infrastructure Investment" with announcements of quantitative ambitions for high-quality infrastructure projects. This was an important result, culminating from the initiative on financing for long-term investment launched by the Russian G20 2013 Presidency [G20 Study Group on Financing for Investment, 2013]. Another initiative, the Global Infrastructure Connectivity Alliance, aimed to enhance the synergy and cooperation among various infrastructure connectivity programs. The membership of the Alliance is open to both G20 and non-G20 governments, the Global Infrastructure Hub (GIH), OECD, MDBs, global and regional in-

${ }^{9}$ Infrastructure, Agriculture, Food Security and Nutrition, Human Resource Development and Employment, Financial Inclusion and Remittances, Domestic Resource Mobilization, Industrialization, Inclusive Business, Energy, Trade and Investment, Anti-Corruption, International Financial Architecture, Growth Strategies, Climate Finance and Green Finance, Innovation, and Global Health [G20, 2016]. 
frastructure programs, and other international organizations. The Leaders asked the WBG to serve as the Secretariat of the Alliance, working closely with all its members.

The G20 Initiative on Supporting Industrialization in Africa and LDCs launched at Hangzhou was taken up by the German G20 presidency, seeking to reduce risks of climate change, contribute to more efficient health systems and strengthen the role of women [German G20 Presidency, 2017].

Employment issues were dealt with in the framework of inclusive development. The leaders emphasized that the benefits from globalization and innovations should be widely shared, creating more and better jobs, reducing inequalities and promoting inclusive labour force participation. They endorsed action plans developed by G20 labour and employment ministers, approved Sustainable Wage Policy Principles, and reiterated commitments to the G20 Entrepreneurship Action Plan. China pledged to contribute to entrepreneurship development by establishing an Entrepreneurship Research Centre on G20 Economies.

On climate change, the G20 members committed to complete domestic procedures in order to join the Paris Agreement as soon as the members' national procedures allowed, affirming the importance of fulfilling the developed countries' UNFCCC commitment to provide financial resources to assist developing countries with respect to both mitigation and adaptation actions.

Looking into the G20's future agenda, the leaders promised to continue to address forced displacement in 2017 with a view to developing concrete actions. Taking over from China, Germany put forward its aim to elaborate solutions to strengthen international institutions and structures, in order to better address displacement and illegal migration. On fighting antimicrobial resistance, the G20 called on the World Health Organization (WHO), the Food and Agriculture Organization of the United Nations (FAO), the World Organisation for Animal Health (OIE) and OECD to collectively report back in 2017 on options to address the problem, including the economic aspects.

\section{What do the Numbers Tell us about China's G20 Presidency?}

Prioritization of the G20 agenda items under the Chinese Presidency is confirmed by data from the quantitative analysis of the G20 2016 documents.

\section{Methodology}

The quantitative analysis is carried out within a functional paradigm. This approach allows a comparison between summit institutions (the G7/8, G20 and BRICS) and within one institution across different presidencies according to three groups of indicators: contribution to the global governance agenda, contribution to multilateralism through engagement with other international institutions, and the performance of global governance functions. It thus contributes to a generation of quantifiable evidence base for assessing the effectiveness of these institutions and informing the re- 
search and forecast of their roles in the system of global governance. Contribution to the global governance agenda is assessed by examining the comparative weights of the key policy priorities in G20 documents, their dynamics in the agenda, and responsiveness to new challenges. The contribution to multilateralism is assessed on the basis of the intensity and modes of engagement with other multilateral institutions. Within the third group of indicators, the focus is on the balance and dynamics of the main global governance functions of deliberation, direction setting, decision making, delivery, and the development of global governance ${ }^{10}$ as expressed in the $\mathrm{G} 20$ documents, including summit declarations, ministerial statements, progress reports, and material issued by officials and working groups.

To enable quantitative analysis, all documents are uploaded into a special database, structured by summits and presidencies, with earmarks of references to international organizations. The data base currently includes 240 documents adopted by the G20 and BRICS, with 165 G20 documents adopted since 2008 and 75 BRICS documents adopted since 2009. The database is updated to integrate new documents once they are agreed upon and published. The special program allows content analysis to be carried out according to the type of documents, functions, policy areas and issues, as well as references and modes of engagement with international organizations. This is done through a search of requested text units, the generation of special samples, and the identification of relevant correlations and statistical data processing. A text unit in the content analysis is earmarked as implementing only one priority.

The quantitative analysis of the priorities in the G20 discourse is carried out on 11 broad issue areas present on the institution's agenda. The comparison is made using absolute and relative data on the number of symbols denoting a priority in the $\mathrm{G} 20$ documents for a certain period (a summit, a presidency, or a cycle). Relative parameters are defined as the share of each priority in the total number of symbols and expressed in percentages.

For the assessment of the G20 engagement with other international institutions, references to international organizations are identified in all the documents in the data base. Assessment is based on three parameters: the number of references to a particular organization made over the period, its share in the total number of references, and the intensity. The intensity is expressed as a ratio of the number of references to the institution to the number of characters (including spaces and punctuation) in the documents as follows: $D_{1}=M_{1} / S_{1}$, where $D_{1}$ is the intensity of references to a particular international institution for a given year (period), $M_{1}$ is the number of references made to this institution during this year (period), and $S_{1}$ is the total number of characters in the

${ }^{10}$ Deliberation is understood as face-to-face discussions of the members encoded in the collective communiqués. Direction-setting is defined as the collective affirmation of shared principles, norms and prescriptions. Decision-making is regarded as credible, clear, collective commitments with sufficient precision, obligation and delegation. Delivery is understood as stated compliance with collective decisions. Global governance development is perceived as G20 capability to use other international institutions and create its own institutions as global governance mechanisms [Kirton, 2013, p. 37-39]. 
documents for this year (period). To make the findings more easily understood, $D_{1}$ is multiplied by 10,000 .

The analysis of the performance of global governance functions is conducted using absolute and relative data on the number of symbols (including spaces and punctuation marks) relating to a certain function in the text. Relative parameters are defined as the share of the function in the total of all functions and expressed in percentages.

The methodology was first tested to assess G7/8 and G20 Effectiveness in Global Governance. For a full description of the methodology, see "The G8-G20 Relationship in Global Governance," edited by Marina V. Larionova and John J. Kirton. Chapter 6 "Assessing G7/8 and G20 Effectiveness in Global Governance" Marina V. Larionova, Mark Rakhmangulov, and Andrey Shelepov.

\section{Key Findings}

Development, innovation and trade warranted unprecedented attention, with development reaching a share of almost $43 \%$ in the discourse (compared to the average of $15 \%$ for the eleven summits), innovation rising tenfold to about $7 \%$ (compared to $0.75 \%$ for the eleven summits) and trade peaking to 7.3 (compared to 2.8 average) (Fig. 1).

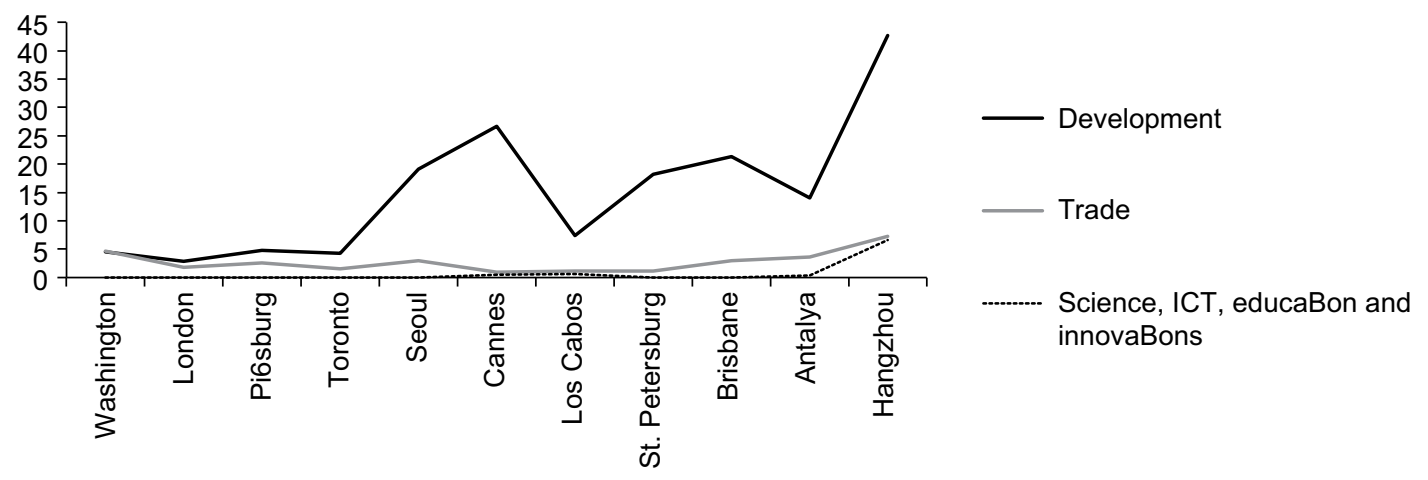

Fig. 1. Share of Development, Trade and Innovation in the G20 Discourse

Source: Author's calculations.

At $2.2 \%$, the share of G20 discourse dedicated to the environment was higher than the overall average (1.42\%) and higher than at any other summit except Cannes and Los Cabos. While lower than for Brisbane and Antalya, energy issues (about 4\%) are comparable to the average for the period (3.4\%) (Fig. 2).

Discussion dedicated to economic issues (at 25\%) was close to the average for the period (27\%). In line with the historical trend, the share of finance issues in the G20's discourse continued to decline, reflecting the G20's role in the division of labour with regard to the regulation of financial markets. The G20 defined the direction for coordinated actions, mandating the FSB, Basel Committee on Banking Supervision 
(BCBS), IMF and other international standards setters, endorsing recommendations, standards, guidelines and procedures developed by the regulators. The G20 remained committed to the implementation of new regulatory measures and pledged its accountability; with the respective international institutions taking responsibility for the development of recommendations and oversight (Fig. 3).

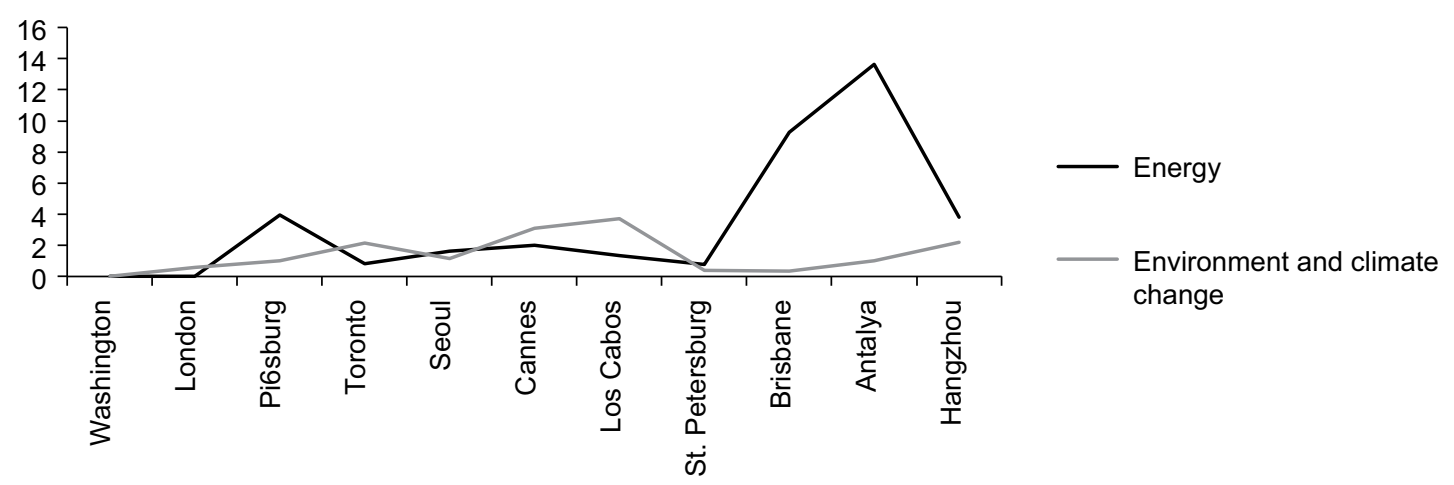

Fig. 2. Share of Energy and the Environment in the G20 Discourse

Source: Author's calculations

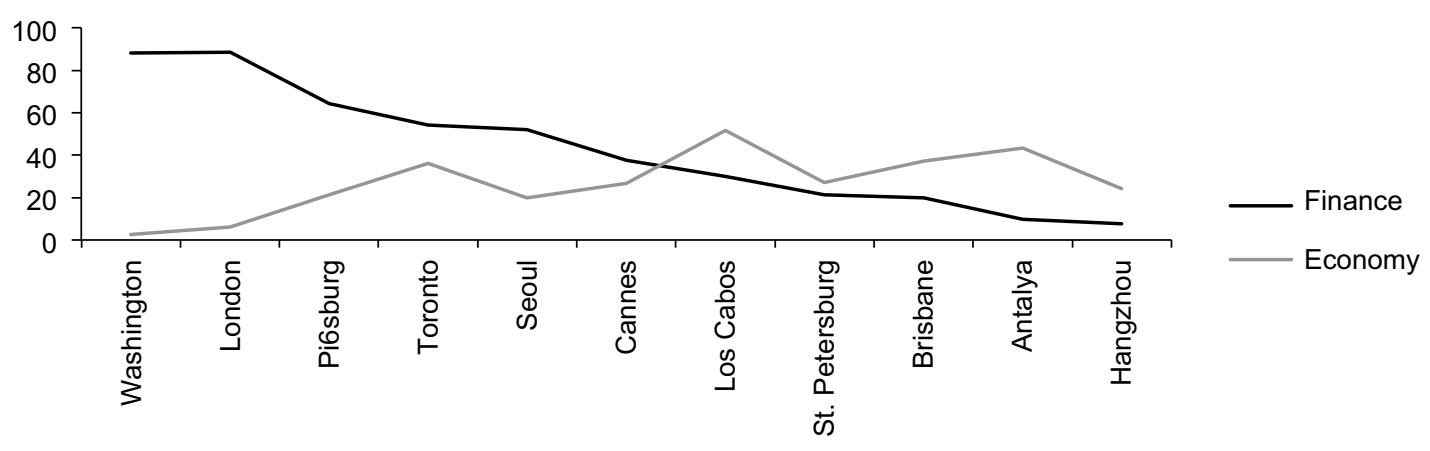

Fig. 3. Share of Finance and Economy in the G20 Discourse

Source: Author's calculations

To ensure continuity, legitimacy and efficiency, the G20 members continued to engage with other international organizations in fulfilling their global governance functions. The intensity of G20 engagement with international organizations, at a level of about 14, was a bit higher than the average since the Washington summit (13.30) (Fig. 4).

The choice of organizations was defined by the presidency's priorities and established trends. Given the UN's role in the Sustainable Development Goals (SDGs), and China's commitment to the UN as the central element of a fair and peaceful multilateral system $(\mathrm{Xi}, 2015 \mathrm{~b})$, it came as no surprise that the intensity of references to the UN was twice as high as the average for the G20 and significantly higher than in any other summit. A similar trend is observed for the WTO and UNCTAD - pillars of the multilateral trade system. The G20's reliance on OECD expertise continued to 


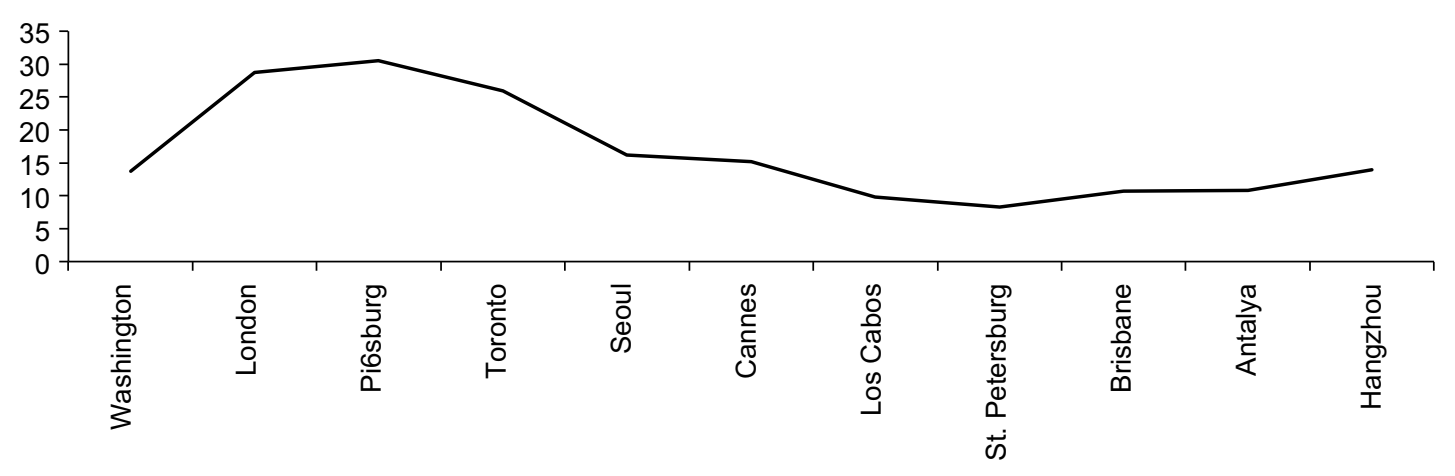

Fig. 4. Intensity of G20 Engagement with International Organizations

Source: Author's calculations.

rise and will obviously increase further. At the request of the G20 leaders, the OECD will support the G20 Task Force, set up at the summit, to promote the G20 agenda on innovation, the new industrial revolution and the digital economy and will be able to influence the G20's future agenda, as well as the G20 members' national policies across the three areas [Larionova, 2017]. The intensity of G20 engagement with the IMF (at 1.75) and the WB was slightly lower than in the previous summits. Intensity of G20 engagement with the IMF fluctuated at about the same level since Seoul and for the WB (at 0.87 ), slowly ebbing from summit to summit since its peak in Toronto. Last but not least, China consolidated G20 dialogue with engagement groups (Fig. 5), most notably with B20 and L20. It referred to both in relation to the implementation of the G20 Initiative to Promote Quality Apprenticeship, but also in the context of joint efforts to ensure that "trade, investment and other public policies, at both national and global levels, remain coherent, complementary and mutually reinforcing" [G20 Trade Ministers, 2016a, para. 20].

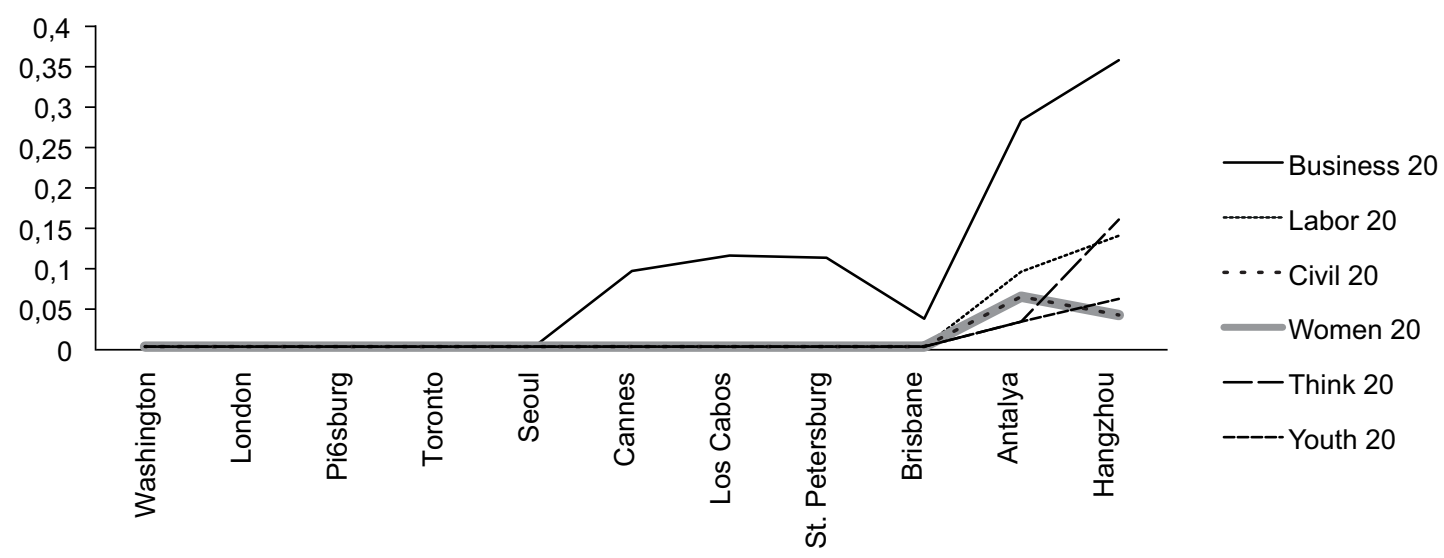

Fig. 5. G20 Engagement with the Outreach Formats

Source: Author's calculations. 
The balance of global governance functions in Hangzhou was tilted toward direction setting, its share amounting to almost $36 \%$, which is significantly higher than the average of $25 \%$ and equals the direction setting share in the leaders' discourse in Washington. This unprecedented hike in direction-setting is clearly connected with the introduction of new policy areas. Apart from the triad of innovation, digitalization and the new industrial revolution, the G20 discussed green finance, excess capacity in steelmaking and other industries, launched the G20 debate on responses to the ongoing refugee crisis and on the prevention and mitigation of antimicrobial resistance. In absence of shock-activated emergency awareness, the G20 members took time to deliberate on these challenges and define a direction for collective action. Though the share of decision-making is lower than in the three previous summits, it constitutes a robust quarter of the discourse, close to the average of $25.46 \%$.

Three documents are focused on the G20 members' delivery on the previous commitments. The 2016 Accountability Assessment Report, prepared with IMF and OECD support, and the Hangzhou Action Plan explored the members' progress towards lifting the aggregate G20 GDP by an additional $2 \%$ by 2018 through the implementation of national growth strategies put forward at the Brisbane and Antalya summits. It highlighted the countries' successes in meeting these goals, but also urged the G20 to accelerate the implementation of the pledges, as only 55 Brisbane and 45 Antalya commitments were fully implemented [G20 Framework Working Group, 2016, p. 1]. The Hangzhou Comprehensive Accountability Report on G20 Development Commitments, the second three years' comprehensive review, tracked progress on 68 G20 DWG commitments agreed upon in the St. Petersburg Development Outlook, noting the completion of 39 commitments, advancement on 24, mixed performance on 3 and the redirection on two of the 2014-2016 pledges.

Though the share of global governance development in the G20 2016 discourse amounted to only $0.5 \%$, decisions provided for the establishment of a G20 Task Force on innovation, the new industrial revolution and the digital economy; the formation of a Global Forum on excess steel capacity; the launch of the Global Infrastructure Connectivity Alliance Initiative; enhancing the status of the G20 DWG; the adoption of G20 Guiding Principles for Global Investment Policymaking and the G20 Strategy for Global Trade Growth; as well as setting up of several research centres. These included the Centre for International Tax Policy Design and Research, the Research Centre on International Cooperation Regarding Persons Sought for Corruption and Asset Recovery in G20 Member States, and an Entrepreneurship Research Centre on G20 Economies. All in all, the breakdown of the global governance functions in the G20 discourse is balanced, with the share of direction setting and decision-making put together amounting to more than $60 \%$ of the discourse, demonstrating the G20's capacity for forging decisions and defining the direction of collective efforts. 


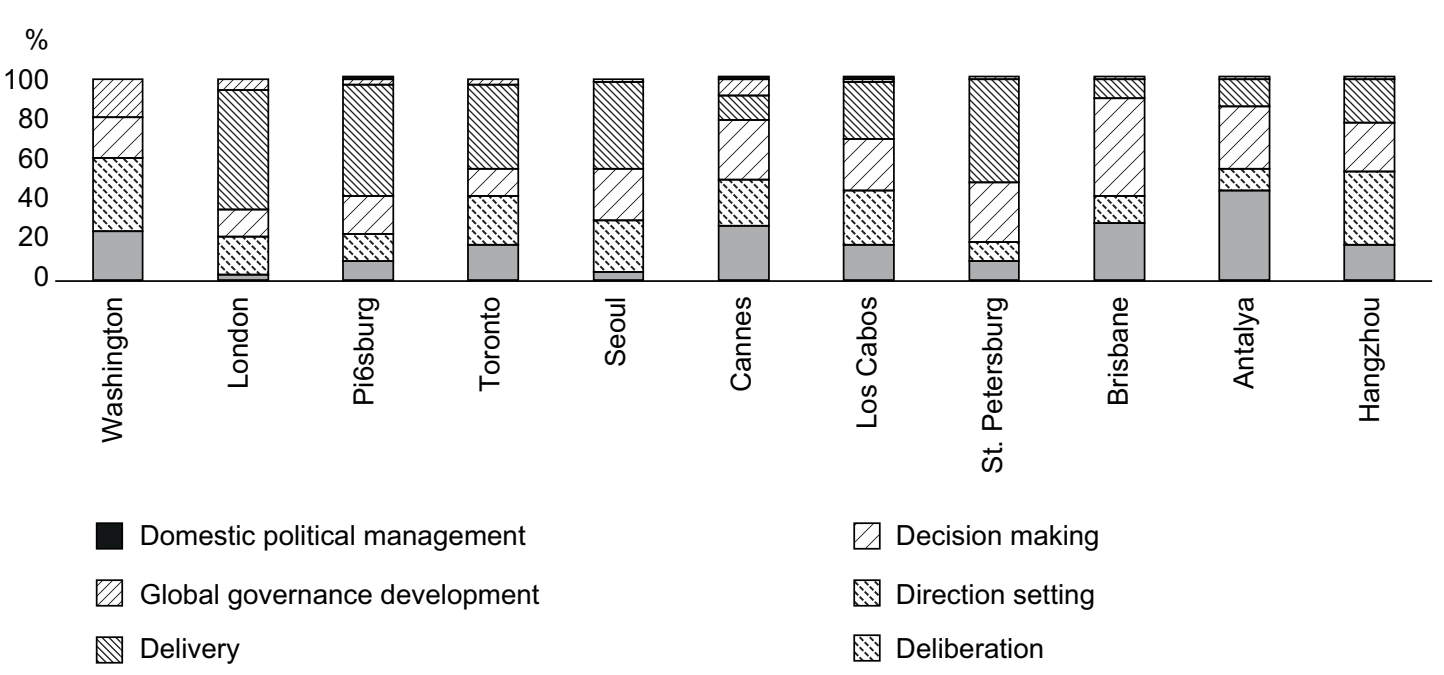

Fig. 6. Dynamics of global governance functions in the G20 discourse

\section{Conclusion}

China ensured its imprint on future G20 cooperation. First, it did so by integrating innovation, the new industrial revolution and the digital economy into its core agenda, generating 137 commitments on innovative growth and setting up the relevant international mechanisms. Second, regarding trade and investment, it facilitated the development and adoption of two documents defining guiding principles for global investment policymaking, and promoting inclusive trade and global value chains. Third, under China's stewardship, the G20 agreed upon three action plans, including Enhancing Energy Access in Asia and the Pacific: Key Challenges, a G20 Voluntary Collaboration Action Plan, the G20 Voluntary Action Plan on Renewable Energy, and the G20 Energy Efficiency Leading Program (EELP), making further progress to address energy access, a cleaner energy future, energy efficiency, the global energy architecture, energy security, as well as market transparency. Fourth, China advanced further G20 cooperation on development through the Action Plan on the 2030 Agenda for Sustainable Development. Fifth, the presidency committed to establish three China-based G20 centres, thus creating opportunities to enhance its influence on the G20 process through evidence base, research and knowledge exchange on key policy areas. China struck a good balance between continuity and innovation in the G20 agenda, contributed to its legitimacy and effectiveness through productive engagement with key international organizations and dialogue with the engagement groups, and consolidated the G20's capacity for direction setting, decision making and delivery. Thus, China's G20 presidency contributed to its development priorities, reflected China's role in the evolving world order, and reaffirmed the status of the G20 as the premier forum for economic cooperation and capability to make globalization work for all. 


\section{References}

China's National Focal Point for UNFCCC (2015) Enhanced Actions on Climate Change. Available at: http://www4.unfccc.int/ndcregistry/PublishedDocuments/China\%20First/China\%27s\%20First\%20 NDC\%20Submission.pdf (accessed 15 January 2017).

Chinese G20 presidency (2016) G20 Summit 2016, China. Available at: http://www.ranepa.ru/images/ media/g20/2016Hangzhou/\%D0\%A1\%D0\%B8\%20\%D0\%A6\%D0\%B7\%D0\%B8\%D0\%BD\%D0\%B F\%D0\%B8\% D0\%BD\%20\%D0\%BF\%D0\%BE\%20\%D0\%BF\%D1\%80\%D0\%B8\%D0\%BE\%D1\%80 $\% \mathrm{D} 0 \% \mathrm{~B} 8 \% \mathrm{D} 1 \% 82 \% \mathrm{D} 0 \% \mathrm{~B} 5 \% \mathrm{D} 1 \% 82 \% \mathrm{D} 0 \% \mathrm{~B} 0 \% \mathrm{D} 0 \%$ BC.pdf (accessed 15 January 2017).

G20 (2016) G20 Action Plan on the 2030 Agenda for Sustainable Development. Available at: http://www. ranepa.ru/images/media/g20/2016Hangzhou/000185879.pdf (accessed 15 January 2017).

G20 Framework Working Group (2016) Hangzhou Accountability Assessment. Available at: http://www. ranepa.ru/images/media/g20/2016Hangzhou/000185868.pdf (accessed: 15.01.2017).

G20 Leaders (2016) Communique Hangzhou Summit, 5 September. Available at: http://www.ranepa. ru/images/media/g20/2016Hangzhou/G20\%20Leaders\% E2\%80\%99\%20Communique\%20Hangzhou\%20Summit.pdf (accessed 17 August 2017).

G20 Study Group on Financing for Investment (2013) G20 Workplan on Financing for Investment. Study Group's Findings and Ways Forward. Available at: http://www.ranepa.ru/images/media/ g20/2013spbsummit/G20\%20Workplan\%20on\%20Financing\%20for\%20Investment.pdf (accessed 15 January 2017).

G20 Trade Ministers (2016a) G20 Trade Ministers Meeting Statement. Available at: http://www.ranepa. ru/images/media/g20/2016Hangzhou/20160711006-4.pdf (accessed 15 January 2017).

G20 Trade Ministers (2016b) Annex II: G20 Strategy for Global Trade Growth (SGTG). Available at: http://www.ranepa.ru/images/media/g20/2016Hangzhou/Annex\%20II.pdf (accessed 15 January 2017).

G20 Trade Ministers (2016c) Annex III: G20 Guiding Principles for Global Investment Policymaking. Available at: http://www.ranepa.ru/images/media/g20/2016Hangzhou/Annex\%20III.pdf (accessed 15 January 2017).

German G20 presidency (2017) Priorities of the 2017 G20 Summit. Available at: http://www.ranepa.ru/ images/media/g20/2017hamburg/2016-g20-praesidentschaftspapier-en.pdf (accessed 15 January 2017).

IMF (2016) World Economic Outlook (WEO) Update "Subdued Demand, Diminished Prospects". Available at: http://www.imf.org/external/pubs/ft/weo/2016/update/01/pdf/0116.pdf (accessed 15 January 2017).

Kirton J. (2013) G20 Governance for a Globalized World. Farnham: Ashgate.

Larionova M. (2011) Sammit "dvadtsatki" v Kannakh: ozhidaniya opravdavshiesya i ne opravdannye [The G20 Summit in Cannes: Expectations Met and Failed]. International Organisations Research Journal, no 4, pp. 5-10. Available at: https://iorj.hse.ru/en/2011-6-4/40735537.html (accessed 17 August 2017). (In Russian.)

Larionova M. (2017) G20: Engaging with International Organizations to Generate Growth. International Organisations Research Journal, vol. 12, no 2, pp. 54-86. (In Russian and English.) DOI: 10.17323/19967845-2017-02-54.

Larionova M., Rakhmangulov M., Sakharov A., Safonkina E., Shelepov A. (2013) Predsedatel'stvo Rossiiskoi Federatcii v "Gruppe dvadtcati”: v poiskakh balansa i putei obespecheniia fiskal'noi ustoichivosti i uverennogo rosta [The Russian Federation G20 Presidency: in Pursuit of a Balance between Fiscal Consolidation and Sustainable Growth]. International Organisations Research Journal, no 4, pp. 122-179. Available at: https://iorj.hse.ru/en/2013-8-4/103578315.html (accessed 17 August 2017). (In Russian.)

OECD (2016) Policies for Sound and Effective Investment in China. Available at: http://www.oecdilibrary.org/economics/policies-for-sound-and-effective-investment-in-china_9789264254985-en (accessed 15 January 2017). 
Shelepov A. (2013) Rezul'taty predsedatel'stva Meksiki v "Gruppe dvadtcati” v 2012 g.: analiz na osnove modeli obespecheniia balansa vneshnikh uslovii i natcional'nykh prioritetov [Results of 2012 G20 Mexican Presidency: Analysis on the Basis of Supply-Demand Model]. International Organisations Research Journal, no 4, pp. 100-121. Available at: https://iorj.hse.ru/en/2013-8-4/103578315.html (accessed 17 August 2017). (In Russian.)

Wang Yi (2016a) Remarks by Foreign Minister Wang Yi at the Media Briefing on the G20 Hangzhou Summit. Available at: http://www.fmprc.gov.cn/mfa_eng/Zxxx_662805/t1368193.shtml (accessed 15 January 2017).

Wang Yi (2016b) Speech by Foreign Minister Wang Yi at the Opening of the Symposium on International Developments and China's Diplomacy in 2016. Available at: http://www.fmprc.gov.cn/mfa_eng/ zxxx_662805/t1421722.shtml (accessed 15 January 2017).

Xi Jinping (2015a) Remarks by H.E. Xi Jinping President of the People's Republic of China on the 2016 G20 Summit in China At the Working Lunch of the G20 Summit. Available at: http://www.fmprc.gov. cn/mfa_eng/topics_665678/xjpcxesgjtldrdscfhhytjhzzdesscldrfzshy/t1315774.shtml (accessed 15 January 2017).

Xi Jinping (2015b) Working Together to Forge a New Partnership of Win-win Cooperation and Create a Community of Shared Future for Mankind. Available at: https://gadebate.un.org/sites/default/files/ gastatements/70/70_ZH_en.pdf (accessed 15 January 2017).

Xi Jinping (2016) Keynote Speech by H.E. Xi Jinping, President of the People's Republic of China, at the Opening Ceremony of the B20 Summit. Available at: http://www.fmprc.gov.cn/mfa_eng/wjdt_665385/ zyjh_665391/t1396112.shtml (accessed 15 January 2017). 


\title{
Ханчжоуский консенсус: наследие для Китая, «Группы двадцати» и мира $a^{1,2}$
}

\author{
М.В. Ларионова, О.И. Колмар
}

Ларионова Марина Владимировна - д.полит.н., директор Центра исследований международных институтов (ЦИМИ) Российской академии народного хозяйства и государственной службы при Президенте РФ (РАНХиГС); Российская Федерация, 119034, Москва, Пречистенская наб., 11; E-mail: larionova-mv@ ranepa.ru

Колмар Ольга Ивановна - научный сотрудник, Центр исследований международных институтов (ЦИМИ) Российской академии народного хозяйства и государственной службы при Президенте РФ (РАНХиГС); Российская Федерация, 119034, Москва, Пречистенская наб., 11; E-mail: kolmar-oi@ranepa.ru

Председательство в «руппе двадиати» перешло от Китая к Турции в конце 2016 г. в период слабой экономической активности и снижения темпов глобального роста. Ожидается, что экономический рост Китая замедлится до 6,3\% в 2016 г. и 6,0\% в 2017 г., что в первую очередь вызвано более слабым ростом инвестиций на фоне продолжения поиска экономикой нового баланса. Признавая, что более низкие темпы роста стали «новой нормалью», руководство Китая в 13-м Пятилетнем плане (на 2016-2020 гг.) установило ежегодный целевой темп роста экономики Китая на уровне не менее 6,5\%. План изменил акцент парадигмы развития Китая со скорости на качество на основе инноваций, координации, «зеленого» развития, открытости и разделения выгод. Это видение стало основой концепции и приоритетов китайского председательства в «Группе двадиати». В статье рассматриваются основные итоги председательства Китая в «Группе двадиати» с упором на ключевые результаты, отражсающе приоритеты страны в области внутреннего развития и международного сотрудничества. Используя качественный и количественный анализ документов «двадиатки» 2016 г. и документов международных организаций, авторы выделяют ключевые решения, принятые на саммите в Ханчжоу, а также тенденции сотрудничества «Группы двадцати» с международными институтами.

Полученные результаты свидетельствуют о том, что приоритеты Китая в области развития, инноваций и торговли были отмечены беспрецедентным вниманием. Доля приоритета содействия развитию в дискурсе достигла почти 43\% (по сравнению со средним показателем в $15 \%$ для всех одиннадиати саммитов), доля инноваций увеличилась в 10 раз и составила около $7 \%$ (по сравнению с показателем 0,75\% для одиннадиати саммитов), а доля торговли достигла максимального в истории значения в 7,3\% (по сравнению со средним показателем 2,8\%). Доля вопросов окружающей среды в дискурсе составила 2,2\%, что выше среднего уровня (1,42\%) и показателей всех предыдущих саммитов, за исключением встреч в Каннах и ЛосКабосе. Хотя доля дискурса по вопросам энергетики оказалась ниже, чем в Брисбене и Анталье, уровень около $4 \%$ сопоставим со средними показателями за всю историю «двадиатки» (3,4\%). Доля экономических проблем (25\%) была близка к средней за весь период(27\%). В соответствии с исторической тенденцией доля финансовых вопросов в дискурсе «Группы двадиати» продолжила снижаться, что отражает роль института в разделении труда в отношении регулирования финансовых рынков.

Интенсивность взаимодействия «двадиатки» с международными организациями была выше, чем в среднем за период с саммита в Вашингтоне. Выбор организаций определялся приоритетами председательства и сложившимися тенденциями. Учитывая роль ООН в достижении целей устойчивого развития и приверженность Китая этой организации как центральному элементу справедливой и способствующей поддержанию мира многосторонней системы, неудивительно, что интенсивность упоминаний ООН была в два раза выше, чем в среднем за весь период существования «двадцатки», и значительно выше, чем в рамках любого другого саммита. Аналогичная тенденция наблюдается в отношении ВТО и ЮНКТАД. «Группа двадиати» продолжила полагаться на экспертный потенциал ОЭСР. Интенсивность взаимодействия «двадиатки» с МВФ и Всемирным банком была несколько ниже, чем в рамках предыдущих председательств. Также немаловажно, что Китай укрепил диалог «двадиатки» с аутрич-группами, прежде всего «деловой двадиаткой» и «профсоюзной двадиаткой».

${ }^{1}$ Исследование выполнено в рамках научно-исследовательской работы государственного задания РАНХиГС «Оценка эффективности “Группы двадцати” и БРИКС на основе результатов мониторинга исполнения решений» (2017 г.).

${ }^{2}$ Статья поступила в редакцию в январе 2017 г. Перевод выполнен Н.А. Спорышевой. 
Основываясь на результатах качественного и количественного анализа, авторы приходят к выводу, что председательство Китая в «Группе двадцати» способствовало реализации приоритетов развития страны и отражало роль Китая в изменяющемся мировом порядке, помогая укрепить статус «двадиатки» в качестве основного форума экономического сотрудничества и наращивая ее возможности по распределению выгод глобализации между всеми гражданами. Авторы утверждают, ито Китай сумел обеспечить вклад в будущее сотрудничество в рамках «двадцатки», во-первых, за счет включения инноваций, новой индустриальной революции и цифровой экономики в ее основную повестку дня, отразившегося в принятии 137 обязательств по инновационному росту и создании соответствующих международных механизмов. Во-вторых, в области торговли и инвестиций китайское председательство способствовало разработке и принятию двух документов, один из которых определяет руководящие принципы для разработки глобальной инвестиционной политики, а другой направлен на стимулирование развития инклюзивной торговли и глобальных иепочек создания стоимости. В-третьих, в рамках председательства Китая «двадиатка» согласовала три плана действий по энергетическому сотрудничеству, включая «Расширение доступа к энергоресурсам в Азиатско-Тихоокеанском регионе: ключевые вызовы и План добровольного сотрудничества «Группы двадиати», «Добровольный план действий “Группы двадиати” по возобновляемым источникам энергии» и «Руководящую программу “Группы двадиати” по энергоэффективности» (EELP), обеспечивших дальнейший прогресс в решении вопросов доступа $\kappa$ энергии, экологически чистой энергетики, энергоэффективности, глобальной энергетической архитектуры, энергетическойбезопасности, а также прозрачности рынка. В-четвертых, Китай стимулировалсотрудничество в рамках «двадиатки» по содействию развитию, основанное на Плане действий по осуществлению Повестки дня в области устойчивого развития до 2030 г. В-пятых, председательство взяло на себя обязательство по созданию трех исследовательских центров «Группы двадцати» в Китае, обеспечив тем самым возможности для усиления своего влияния на процесс работы «двадиатки» на основе использования базы фактических данных, исследований и обмена знаниями в ключевых областях политики. Китай добился хорошего баланса преемственности и новаторства в повестке дня «двадцатки», способствовал повышению ее легитимности и эффективности благодаря продуктивному взаимодействию $с$ ключевыми международными организациями и диалогу с аутрич-партнерами, а также укрепил потенциал «Группы двадцати» по реализации функций определения направлений действий, принятия решений и их исполнения.

Ключевые слова: глобальное управление; международные организации; неформальные институты высшего уровня; эффективность; легитимность; инновации; новая индустриальная революция; цифровая экономика; «Группа двадцати»; Китай

Для цитирования: Ларионова М.В., Колмар О.И. Ханчжоуский консенсус: наследие для Китая, «Группы двадцати» и мира // Вестник международных организаций. 2017. T. 12. № 3. С. 53-72. DOI: 10.17323/19967845-2017-03-53

\section{Литература}

Ларионова М.В. (2011) Саммит «двадцатки» в Каннах: ожидания оправдавшиеся и не оправданные // Вестник международных организаций. Т. 6. № 4. С. 5-10. Режим доступа: https://iorj.hse.ru/2011-64/40735537.html (дата обращения: 17.08.2017).

Ларионова М.В. (2017) «Группа двадцати»: взаимодействие с международными организациями для обеспечения роста // Вестник международных организаций. Т. 12. № 2. C. 54-86. DOI:10.17323/19967845-2017-02-54.

Ларионова М.В., Рахмангулов М.Р., Сафонкина Е.А., Сахаров А.Г., Шелепов А.В. (2013) Председательство Российской Федерации в «Группе двадцати»: в поисках баланса и путей обеспечения фискальной устойчивости и уверенного роста // Вестник международных организаций. Т. 8 . № 4. С. 122-179. Режим доступа: https://iorj.hse.ru/2013-8-4/103578315.html (дата обращения: 17.08.2017).

Лидеры «Группы двадцати» (2016) Коммюнике лидеров «Группы двадцати» по итогам саммита в Ханчжоу (КНР). Режим доступа: http://www.ranepa.ru/images/media/g20/2016Hangzhou/G20\%20Leaders\%E2\%80\%99\%20Communique\%20Hangzhou\%20Summit.pdf (дата обращения: 15.01.2017).

Шелепов А.В. (2013) Результаты председательства Мексики в «Группе двадцати» в 2012 г.: анализ на основе модели обеспечения баланса внешних условий и национальных приоритетов // Вестник международных организаций. Т. 8. № 4. С.100-121. Режим доступа: https://iorj.hse.ru/2013-8-4/103578292. html (дата обращения: 15.01.2017). 
China's National Focal Point for UNFCCC (2015) Enhanced Actions on Climate Change. Режим доступа: http://www4.unfccc.int/ndcregistry/PublishedDocuments/China\%20First/China\%27s\%20First\%20 NDC\%20Submission.pdf (дата обращения: 15.01.2017).

Chinese G20 presidency (2016) G20 Summit 2016, China. Режим доступа: http://www.ranepa.ru/images/ media/g20/2016Hangzhou/\%D0\%A1\%D0\%B8\%20\%D0\%A6\%D0\%B7\%D0\%B8\%D0\%BD\%D0\%BF\%D 0\%B8\%D0\%BD\%20\%D0\%BF\%D0\%BE\%20\%D0\%BF\%D1\%80\%D0\%B8\%D0\%BE\%D1\%80\%D0\%B8\% D1\%82\%D0\%B5\%D1\%82\%D0\%B0\%D0\%BC.pdf (дата обращения: 15.01.2017).

G20 (2016) G20 Action Plan on the 2030 Agenda for Sustainable Development. Режим доступа: http://www. ranepa.ru/images/media/g20/2016Hangzhou/000185879.pdf (дата обращения: 15.01.2017).

G20 Framework Working Group (2016) Hangzhou Accountability Assessment. Режим доступа: http://www. ranepa.ru/images/media/g20/2016Hangzhou/000185868.pdf (дата обращения: 15.01.2017).

G20 Study Group on Financing for Investment (2013) G20 Workplan on Financing for Investment. Study Group's Findings and Ways Forward. Режим доступа: http://www.ranepa.ru/images/media/g20/2013spbsummit/ G20\%20Workplan\%20on\%20Financing\%20for\%20Investment.pdf (дата обрашения: 15.01.2017).

G20 Trade Ministers (2016a) G20 Trade Ministers Meeting Statement. Режим доступа: http://www.ranepa. ru/images/media/g20/2016Hangzhou/20160711006-4.pdf (дата обращения: 15.01.2017).

G20 Trade Ministers (2016b) Annex II: G20 Strategy for Global Trade Growth (SGTG). Режим доступа: http://www.ranepa.ru/images/media/g20/2016Hangzhou/Annex\%20II.pdf (дата обращения: 15.01.2017).

G20 Trade Ministers (2016c) Annex III: G20 Guiding Principles for Global Investment Policymaking. Режим доступа: http://www.ranepa.ru/images/media/g20/2016Hangzhou/Annex\%20III.pdf (дата обращения: 15.01.2017).

German G20 presidency (2017) Priorities of the 2017 G20 Summit. Режим доступа: http://www.ranepa.ru/ images/media/g20/2017hamburg/2016-g20-praesidentschaftspapier-en.pdf (accessed January 2017).

IMF (2016) World Economic Outlook (WEO) Update "Subdued Demand, Diminished Prospects". Режим доступа: http://www.imf.org/external/pubs/ft/weo/2016/update/01/pdf/0116.pdf (дата обращения: 15.01.2017).

Kirton John (2013) G20 Governance for a Globalized World. Farnham: Ashgate.

OECD (2016) Policies for Sound and Effective Investment in China. Режим доступа: http://www.oecd-ilibrary.org/economics/policies-for-sound-and-effective-investment-in-china_9789264254985-en (дата обращения: 15.01.2017).

Wang Yi (2016a) Remarks by Foreign Minister Wang Yi At the Media Briefing on the G20 Hangzhou Summit. Режим доступа: http://www.fmprc.gov.cn/mfa_eng/zxxx_662805/t1368193.shtml (дата обращения: 15.01.2017).

Wang Yi (2016b) Speech by Foreign Minister Wang Yi at the Opening of the Symposium on International Developments and China's Diplomacy in 2016. Режим доступа: http://www.fmprc.gov.cn/mfa_eng/zxxx_662805/ t1421722.shtml (дата обращения: 15.01.2017).

Xi Jinping (2015a) Remarks by H.E. Xi Jinping President of the People's Republic of China on the 2016 G20 Summit in China At the Working Lunch of the G20 Summit. Режим доступа: http://www.fmprc.gov.cn/mfa eng/topics_665678/xjpcxesgjtldrdscfhhytjhzzdesscldrfzshy/t1315774.shtml (дата обращения: 15.01.2017).

Xi Jinping (2015b) Working Together to Forge a New Partnership of Win-win Cooperation and Create a Community of Shared Future for Mankind. Режим доступа: https://gadebate.un.org/sites/default/files/gastatements/70/70_ZH_en.pdf (дата обращения: 15.01.2017).

Xi Jinping (2016) Keynote Speech by H.E. Xi Jinping, President of the People's Republic of China, at the Opening Ceremony of the B20 Summit. Режим доступа: http://www.fmprc.gov.cn/mfa_eng/wjdt_665385/ zyjh_665391/t1396112.shtml (дата обрашения: 15.01.2017). 